\title{
PENGARUH KARAKTERISTIK INDIVIDU TERHADAP KINERJA AUDITOR
}

\author{
Ceacilia Sri Mindarti \\ Fakultas Ekonomika dan Bisnis, Universitas STIKUBANK \\ ceaciliasrimindarti@gmail.com
}

\begin{abstract}
This study aims to analyze the influence of individual characteristics of auditors in terms of locus of control and organizational commitment to the performance of auditors. The theories that be used in this study are attribution theory and goal setting theory. Auditors in a public accounting firm in Indonesia with a minimum term of one year are selected as samples in this study. The research data were collected by questionnaires, which were processed using regression analysis. The results showed that individual characteristics which are locus of control and organizational commitment were influenced the performance of auditors. The results will contribute to the development of the auditing literature, especially regarding to the influence of individual characteristics on the auditor's performance as well as performance of auditors.
\end{abstract}

Keywords: locus of control, organizational commitment, auditor's performance, attribution theory, goal setting theory

\section{PENDAHULUAN}

Persaingan dunia usaha akan semakin meningkat dalam menghadapi ASEAN Economic Community (AEC). AEC ini akan memiliki dampak positif dan negatif bagi perkembangan kantor akuntan publik. Pembentukan komunitas ekonomi tersebut akan memberikan implikasi terciptanya pasar tunggal dan dapat memicu persaingan bisnis di wilayah Asia Tenggara. ASEAN Economic Community memberikan peluang dan keuntungan bagi dunia bisnis, karena terjadi peningkatan akses pasar antar negara-negara ASEAN. Perusahaan-perusahaan dapat memperluas cakupan pangsa pasar, aliran investasi, modal dan tenaga kerja yang terampil. Namun demikian kondisi tersebut juga memiliki konsekuensi bagi dunia bisnis. Hal ini terjadi karena dengan terbukanya akses dari kawasan ASEAN tentunya terjadi peningkatan tuntutan pengguna laporan keuangan terhadap disajikannya laporan keuangan yang berintegritas tinggi.

Auditor memiliki peran yang sangat penting dalam memberikan jaminan atas kewajaran laporan keuangan. Jaminan tersebut dinyatakan dalam opini yang menyatakan kewajaran laporan keuangan klien. Opini auditor atas laporan keuangan 
akan digunakan sebagai acuan oleh para pengguna laporan keuangan dalam mengambil keputusan. Opini yang tidak sesuai dengan kondisi klien akan dianggap sebagai informasi yang menyesatkan. Untuk dapat menghasilkan opini yang terpercaya auditor harus memiliki bukti kompeten yang memadai dan melaksanakan seluruh tahapan audit dengan seksama.

Dalam melaksanakan tugasnya, auditor harus mengikuti standar audit. Standar tersebut terdiri dari standar umum, standar pekerjaan lapangan, standar pelaporan serta kode etik akuntan. Standar auditing merupakan pedoman bagi auditor dalam menjalankan tanggung jawab profesionalnya. Standar tersebut harus dipatuhi oleh akuntan publik yang beroperasi sebagai auditor independen (Arens dan Loebbecke 2013).

Standar audit merupakan pedoman bagi auditor dalam menjalankan tugasnya. Kenyataan di lapangan menunjukkan bahwa banyak auditor melakukan penyimpangan terhadap kode etik dan standar audit (Irawati et al., 2005). Penyimpangan terhadap standar dan prosedur audit dapat memengaruhi kinerja auditor, bahkan dapat menyebabkan kegagalan audit (Donnelly et al., 2003).

Faktor-faktor yang memengaruhi kinerja auditor dapat berupa faktor individu dan lingkungan (Bonner dan Sprinkle 2002). Penelitian ini lebih difokuskan kepada faktor karakteristik individu. Hal ini didasarkan pada teori atribusi yang menyatakan bahwa sumber perilaku individu bisa dari faktor internal (karakteristik individu) dan faktor eksternal (lingkungan). Berdasarkan pada teori tersebut maka faktor penyebab tidak sesuainya kinerja auditor dari yang diharapkan dapat bersumber dari karakteristik individu auditor. Pernyataan serupa disampaikan oleh Donnelly et al. (2003), yang menyatakan bahwa faktor karakteristik individu auditor mempunyai potensi memengaruhi kinerja auditor. Motivasi lain yang mendorong penelitian ini adalah adanya inkonsistensi hasil dari penelitian sebelumnya.

Beberapa peneliti telah mencoba menguji pengaruh komitmen organisasi dan locus of control terhadap kinerja auditor, namun hasilnya masih tidak konsisten. Variabel pertama yang digunakan dalam peneltiian ini adalah komitmen organisasi. Komitment organisasi menurut Robbins (2011) sebagai suatu keadaan dimana seseorang karyawan memihak organisasi tertentu serta tujuan-tujuan dan keinginannya untuk mempertahankan keanggotaan dalam organisasi tersebut. Trisnaningsih (2007) menemukan bahwa komitmen organisasi berpengaruh positif terhadap kinerja auditor, akan tetapi Yunanto (2014) menemukan bahwa komitmen organisasi tidak berpengaruh terhadap kinerja auditor. Locus of control adalah variabel lain yang digunakan dalam penelitian ini. Locus of control menggambarkan tingkat keyakinan seseorang tentang sejauh mana mereka dapat mengendalikan faktor-faktor yang memengaruhi keberhasilan atau kegagalan yang dialaminya (Lefcourt 1982 dalam Silaban 2013). Individu-individu yang cenderung menghubungkan hasil dengan usaha mereka sendiri atau individu yang percaya 
bahwa kejadian-kejadian berada dibawah pengendalaian mereka mengacu pada locus of control internal. Sementara individu dengan locus of control eksternal percaya bahwa mereka tidak dapat mengendalikan kejadian-kejadian atau hasil yang mereka capai (Spector 1982). Provita (2009) menemukan bahwa locus of control berpengaruh negatif terhadap kinerja auditor. Temuan ini didukung oleh Srimindarti (2010) serta Irawati et al. (2005). Hal yang berbeda ditemukan oleh Wijaya (2014) bahwa locus of control tidak berpengaruh terhadap kinerja auditor.

Kinerja auditor yang tidak sesuai harapan merupakan sesuatu yang sangat tidak diinginkan dalam pelaksanaan audit. Akan tetapi, dalam kenyataan di lapangan menunjukkan adanya kesenjangan antara kinerja aktual auditor dengan kinerja yang diharapkan. Penerimaan tersebut tidak terlepas dari karakteristik individu yang ikut menentukan kinerja auditor. Berdasarkan pada permasalahan tersebut, maka pertanyaan penelitian ini adalah sebagai berikut. (1) Bagaimana pengaruh locus of control terhadap kinerja auditor? (2) Bagaimana pengaruh komitmen organisasi terhadap kinerja auditor? Penelitian ini diharapkan bermanfaat bagi pengembangan literatur khususnya di bidang audit, terutama tentang pengaruh karakteristik auditor terhadap kinerja auditor. Hasil penelitian ini juga diharapkan dapat digunakan sebagai pertimbangan bagi partner kantor akuntan publik untuk membuat kebijakan guna meningkatkan kinerja auditornya.

\section{TELAAH PUSTAKA}

\section{Teori Atribusi (Attribution Theory)}

Teori atribusi akan digunakan untuk menjelaskan hubungan antara karakteristik individu auditor terhadap kinerja auditor. Teori ini menyatakan mengenai bagaimana seseorang menjelaskan penyebab perilaku orang lain atau dirinya sendiri (Luthans 1998). Penyebab seseorang memilih suatu perilaku bisa berasal dari internal (dispositional attributions) dan eksternal (situational attributions). Penyebab internal cenderung mengarah pada aspek perilaku individual, sesuatu yang telah ada dalam diri seseorang seperti sifat pribadi, persepsi diri, kemampuan dan motivasi. Sedangkan penyebab eksternal lebih mengarah pada lingkungan yang memengaruhi perilaku seseorang seperti kondisi sosial, nilai sosial dan pandangan masyarakat. Berdasarkan teori tersebut, tindakan seorang auditor dalam melaksanakan penugasan audit sesuai dengan prosedur sehingga kinerjanya maksimal dapat disebabkan oleh faktor internal individu yang bersangkutan maupun faktor lingkungan.

\section{Teori Penetapan Tujuan (Goal Setting Theory)}

Teori penetapan tujuan telah banyak digunakan untuk menjelaskan perilaku individu dalam tatanan organisasi (Robbins 2011). Teori ini menguraikan hubungan antara tujuan yang dimiliki dan perilaku kerja. Konsep dasar teori ini menyatakan 
bahwa tujuan yang dimiliki oleh individu akan memengaruhi perilaku kerjanya (Lock dan Latham 1990). Teori ini memfokuskan pada perbedaan aspek sifat manusia atau aspek internal dan berusaha mengungkap proses pemikiran dalam menentukan pilihan. Teori penetapan tujuan yang dikembangkan oleh Lock dan Latham (1990) menyatakan bahwa faktor-faktor penting yang memengaruhi pilihan yang dibuat oleh individu dapat dilihat dari seberapa besar usaha yang dilakukan oleh individu tersebut. Adapun besarnya usaha yang dilakukan oleh individu akan tergantung pada pilihan yang dibuat oleh individu tersebut dan seberapa besar komitmen mereka terhadap tujuan tersebut. Individu menginginkan untuk mencapai tujuan jangka pendek dan jangka panjang mereka, kemudian keinginan ini memengaruhi perilaku mereka secara spesifik.

Teori penetapan tujuan dalam penelitian ini digunakan untuk menjelaskan bahwa tindakan auditor dalam melaksanakan tahapan audit dilakukan sesuai prosedur sehingga kinerjanya maksimal. Perilaku auditor dalam melaksanakan pekerjaan disebabkan karena adanya motivasi tertentu. Dengan demikian tujuan yang dimiliki oleh auditor akan menentukan pilihan tindakan yang dilakukan auditor. Setiap auditor memiliki tujuan personal masing-masing. Auditor menginginkan untuk mencapai tujuan-tujuan mereka, baik tujuan jangka pendek maupun tujuan jangka panjang. Tujuan tersebut selanjutnya menentukan seberapa besar usaha yang akan dilakukan oleh auditor. Semakin tinggi komitmen auditor dalam mencapai tujuan akan mendorong auditor untuk melakukan usaha yang semakin keras. Tindakan auditor dalam melaksanakan pekerjaan sesuai prosedur sangat tergantung pada tujuan yang dimiliki oleh auditor. Seorang auditor mungkin akan melakukan pekerjaan sesuai prosedur dengan tujuan untuk memiliki kinerja yang baik sehingga pada saatnya nanti dapat memperoleh jabatan yang lebih tinggi. Sementara auditor lain memilih melakukan tindakan sebaliknya karena memiliki tujuan tertentu. Singkat kata, tujuan yang dimiliki oleh auditor akan mempengaruhi perilaku auditor secara spesifik dalam melaksanakan pekerjaan audit.

\section{Locus of Control}

Locus of control merupakan suatu konsep yang dikembangkan oleh Rotter pada tahun 1966. Rotter menyatakan bahwa individu-individu mengembangkan ekspektasi-ekspektasi mengenai kesuksesan mereka dalam situasi terentu akan tergantung pada perilaku personal mereka atau dikendalikan oleh pihak diluar dirinya (Donnelly et al., 2003). Individu-individu yang cenderung menghubungkan hasil dengan usaha mereka sendiri atau individu yang percaya bahwa kejadian-kejadian berada di bawah pengendalian mereka mengacu pada locus of control internal. Sementara individu dengan locus of control eksternal percaya bahwa mereka tidak dapat mengendalikan kejadian-kejadian atau hasil yang mereka capai (Spector 1982). Jadi secara internal atau secara eksternal, individu dapat mengatasi situasi tertentu secara identik. Tindakan-tindakan mereka akan memiliki pengaruh yang sangat berbeda pada kehidupan mereka (Donnelly et al., 2003). 
Locus of control atau pusat kendali menunjuk pada sejauh mana individu meyakini bahwa dia dapat mengendalikan faktor-faktor yang memengaruhi dirinya. Individu yang memiliki pusat kendali internal tinggi meyakini bahwa perilaku dan tindakannya (meskipun tidak secara total) memengaruhi berbagai peristiwa dalam hidupnya. Individu dengan pusat kendali eksternal yang tinggi meyakini bahwa kesempatan, nasib atau orang lain merupakan faktor penentu utama bagi berbagai hal yang terjadi pada dirinya (Setiawan dan Ghozali 2006).

\section{Komitmen Organisasi}

Komitmen organisasi telah diidentifikasi sebagai suatu faktor kritis dalam memahami dan menjelaskan hubungan perilaku kerja para karyawan dalam organisasi. Parker dan Kohlmeyer (2005) mendefinisikan komitmen organisasi sebagai kekuatan relatif identifikasi individual terhadap suatu organisasi dan keterlibatannya dalam suatu organisasi tertentu. Tiga faktor yang terkait dalam organisasi yaitu: (1) kepercayaan yang pasti serta penerimaan terhadap nilai-nilai dan tujuan organisasi; (2) keinginan untuk berusaha sekuat tenaga demi organisasi; dan (3) keinginan yang kuat untuk tetap menjadi anggota organisasi.

Aliran attitudinal mendefinisikan komitmen sebagai kekuatan relatif identifikasi individual terhadap suatu organisasi dan keterlibatannya dalam suatu organisasi tertentu, yang dicirikan oleh tiga faktor psikologis yaitu: (1) keinginan yang kuat untuk tetap menjadi anggota organisasi tertentu; (2) keinginan untuk berusaha sekuat tenaga demi organisasi; dan (3) kepercayaan yang pasti serta penerimaan terhadap nilai-nilai dan tujuan-tujuan organisasi (Robbins 2011). Dalam perkembangannya, perspektif attitudinal memandang bahwa komitmen organisasi bersifat multidimensi dan tersusun atas affective commitment, continuance commitment dan normative commitment (Setiawan dan Ghozali 2006). Affective commitment merupakan keterikatan emosional terhadap organisasi dimana pegawai mengidentifikasi diri dengan organisasi dan menikmati keanggotaan dalam organisasi. Continuance commitment merupakan biaya yang dirasakan yaitu berkaitan dengan kerugian yang terjadi jika meninggalkan organisasi. Adapun normative commitment merupakan suatu tanggung jawab untuk tetap berada dalam organisasi.

\section{Kinerja Auditor}

Kinerja merupakan usaha dan perilaku individu yang diarahkan untuk mencapai tujuan organisasi. Kinerja individu menunjukkan tingkatan tugas yang dibebankan kepada individu secara aktual dicapai. Kinerja individu bisa melibatkan perilaku yang abstrak seperti perencanaan dan supervisi (Maryanti 2005).

Blumberg dan Pringle (1982) mengemukakan bahwa kinerja individu merupakan fungsi dari tiga dimensi yaitu keinginan, kapasitas dan kemungkinan. Keinginan merupakan faktor yang memotivasi karyawan untuk melakukan suatu tugas organisasi. Kapasitas merupakan kemampuan, keterampilan dan energi yang 
dimiliki oleh individu untuk melaksanakan pekerjaan yang dibebankan kepadanya. Sementara kemungkinan merupakan faktor lingkungan kerja yang memfasilitasi kinerja.

Kinerja individual auditor menunjukkan kemampuan seorang auditor dalam melaksanakan pekerjaan sesuai standar audit yang telah ditetapkan. Kinerja auditor dievaluasi dalam setiap penugasan dan dilaporkan dalam laporan evaluasi penugasan perorangan yang dimiliki perusahaan (Arens dan Loebecke 2013). Tujuan utama dari evaluasi kinerja individu adalah memberi masukan kepada individu agar individu melakukan tugas secara efektif (Locke dan Latham 1990). Evaluasi kinerja auditor akan mengukur keberhasilan seorang auditor dalam melaksanakan penugasan audit sesuai dengan prosedur yang telah ditetapkan sebelumnya (Arens dan Loebecke 2013). Kinerja auditor diukur dari berbagai dimensi. Dimensi-dimensi tersebut meliputi perencanaan, supervisi, koordinasi dan pemilihan staff (Donnelly et al., 2003). Berikut ini akan dipaparkan berbagai dimensi pengukuran kinerja auditor. Paparan dimulai dari perencanaan, investigasi, supervisi, koordinasi dan pemilihan staf.

Program kerja audit yang akan dilaksanakan harus direncanakan dengan matang. Perencanaan ini bermanfaat untuk memperoleh bahan bukti kompeten yang cukup, menekan biaya audit, dan untuk menghindari salah pengertian dengan klien (Arens dan Loebecke 2013). Standar pekerjaan lapangan menyatakan bahwa jika dalam program kerja audit digunakan asisten, maka harus ada pengawasn secara seksama. Tindakan supervisi ini dilakukan untuk memastikan agar semua tahap yang telah direncanakan dapat berjalan sebagaimana mestinya (Arens dan Loebecke 2013). Penugasan audit seringkali melibatkan suatu tim sehingga dibutuhkan kerjasama dan komunikasi antar anggota tim. Tindakan koordinasi memiliki peran yang sangat penting agar setiap anggota tim memahami tugas yang menjadi tanggung jawabnya sehingga tahapan yang direncanakan dapat diselesaikan tepat waktu. Seorang auditor juga dituntut untuk memenuhi kualifikasi teknis dan berpengalaman dalam bidang industri yang dijalani kliennya. Oleh karena itu pemilihan staf untuk suatu penugasan audit harus mempertimbangkan kesesuaian kemampuan dan pengalaman staff tersebut dengan industri klien (Arens dan Loebecke 2013).

\section{Pengaruh Locus of Control terhadap Kinerja Auditor}

Penelitian ini menguji pengaruh locus of control terhadap kinerja auditor. Teori yang digunakan untuk menjelaskan pengaruh ini adalah attribution theory (Luthans 1998). Teori ini menyatakan bahwa penyebab seseorang memilih suatu perilaku bisa berasal dari internal (dispositional attributions) dan eksternal (situational attributions). Individu-individu dengan locus of control eksternal kurang memiliki kemampuan berjuang dengan usaha sendiri, serta kurang memiliki kemampuan untuk mengorganisasi informasi dalam memori (Koonce dan Mercer 2005), sehingga akan mengalami konflik yang relatif lebih banyak berkaitan dengan 
pekerjaan mereka (Donnelly et al., 2003). Kondisi ini akan mengakibatkan individu tersebut cenderung memiliki kinerja yang tidak maksimal. Berdasarkan pada paparan di atas maka dirumuskan hipotesis sebagai berikut.

H1: Locus of control berpengaruh negatif terhadap kinerja auditor.

\section{Pengaruh Komitmen Organisasi terhadap Kinerja Auditor}

Komitmen organisasi merupakan suatu keadaan atau derajat sejauh mana seorang karyawan memihak pada suatu organisasi tertentu dan tujuan-tujuannya, serta berniat memelihara keanggotaan dalam organisasi itu. Komitmen karyawan pada organisasi merupakan salah satu sikap yang merefleksikan perasaan suka atau tidak suka dari seorang karyawan terhadap organisasi tempat mereka bekerja (Robbins 2011).

Individu dengan komitmen organisasi tinggi akan bekerja sesuai dengan standar meskipun berada dalam situasi yang menekan. Komitmen pada organisasi merupakan alat prediksi yang sangat baik untuk beberapa perilaku penting, diantaranya adalah untuk melakukan pekerjaan melebihi apa yang seharusnya dikerjakan (Irawati et al., 2005). Malone dan Roberts (1996) menyatakan bahwa auditor dengan komitmen organisasi yang lebih tinggi akan cenderung memiliki kinerja yang maksimal dengan tujuan mempertahankan pekerjaan. Dasar teori yang digunakan untuk menjelaskan hubungan ini adalah goal setting theory. Sehingga diturunkan hipotesis sebagai berikut.

H2: Komitmen organisasi berpengaruh positif terhadap kinerja auditor.

\section{METODA PENELITIAN}

\section{Sampel dan Data Penelitian}

Populasi dalam penelitian ini adalah auditor yang bekerja pada kantor akuntan publik di Indonesia. Untuk menentukan sampel yang diambil dalam penelitian ini, digunakan metode pengambilan sampel bertujuan, dengan kriteria auditor yang telah bekerja pada KAP bersangkutan minimal satu tahun. Alasan dilakukannya kriteria ini karena auditor yang bekerja kurang dari satu tahun belum memiliki kewenangan mengambil keputusan, sebab umumnya mereka masih menjadi asisten dan segala keputusan ditentukan oleh supervisornya.

Data dalam riset ini adalah data primer yang diperoleh dari penyebaran kuesioner kepada para auditor berdasarkan populasi dan penentuan sampel yang telah ditentukan. Pengumpulan data melalui penyebaran kuesioner diperoleh secara langsung tertuju kepada para auditor dengan mendatangi kantor KAP, mail survey dan bantuan penghubung yang mempunyai akses pada sejumlah KAP di Indonesia. 


\section{Operasionalisasi Variabel Penelitian}

Riset ini menguji pengaruh variabel locus of control (LoC) terhadap penerimaan under-reporting time. Variabel LoC diukur dengan menggunakan pertanyaan dari Donnelly et al. (2003). Instrumen ini terdiri dari enam belas pertanyaan. Skor yang lebih tinggi menggambarkan locus of control eksternal. Variabel komitmen organisasi diukur dengan menggunakan pertanyaan yang dikembangkan oleh Mowday et al. (1979). Instrumen ini terdiri dari sembilan pertanyaan. Skor yang lebih tinggi menggambarkan komitmen organisasi yang tinggi. Variabel kinerja auditor diukur dengan menggunakan pertanyaan yang dikembangkan dari Chao dan Georgia (1994) dalam Donnelly et al. (2003). Instrumen ini terdiri dari lima pertanyaan. Seluruh teknik pengukuran menggunakan skala Likert dengan nilai antara satu sampai tujuh. Skor yang lebih tinggi menggambarkan kinerja yang tinggi, sedangkan skor yang rendah menggambarkan kinerja yang rendah. Indikator untuk variabel penelitian ditampilkan lengkap dalam lampiran.

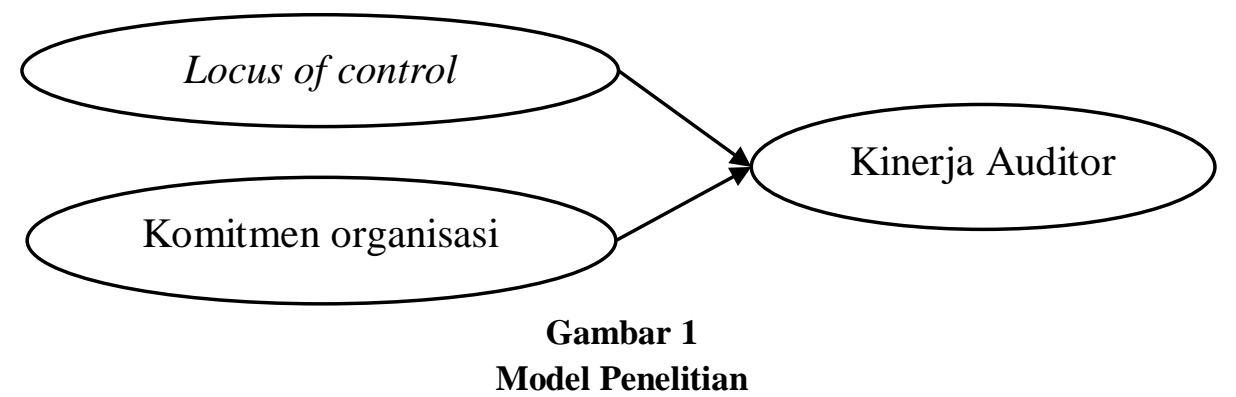

\section{HASIL PEMBAHASAN}

Jumlah kuesioner yang dikirimkan dalam penelitian ini berjumlah 852 buah, dan jumlah kuesioner yang kembali dan dapat diolah dalam penelitian ini adalah 136 buah kuesioner. Dengan demikian tingkat pengembalian kuesioner ini adalah 15,96 persen. Responden penelitian ini tersebar dari sebelas kota di Indonesia meliputi Medan, Jakarta, Bandung, Semarang, Yogyakarta, Solo, Surabaya, Denpasar, Mataram, Makassar dan Manado.

Responden penelitian ini juga memiliki variasi tingkat pendidikan dari D3 hingga S3 yang menempati berbagai tingkat posisi di KAP, dari yunior, senior, manajer hingga partner. Profil responden secara lengkap disajikan pada Tabel 1. 
Tabel 1

Profil Responden

\begin{tabular}{llcc}
\hline \multicolumn{1}{c}{ Keterangan } & Jumlah & Persentase \\
\hline Gender: & Pria & 84 & 61,76 \\
& Wanita & 52 & 38,24 \\
& D3/ Diploma & 30 & 22,05 \\
& S1/ Sarjana & 98 & 72,05 \\
& Sz & 6 & 4,41 \\
& S3 & 2 & 1,49 \\
Lama bekerja: & $1-3$ tahun & 93 & 68,38 \\
& $4-6$ tahun & 36 & 26,47 \\
& $7-10$ tahun & 3 & 2,20 \\
& $>10$ tahun & 41 & 2,95 \\
Posisi di KAP: & Partner & 4 & 2,95 \\
& Manajer & 6 & 4,41 \\
& Senior/ Supervisor & 14 & 10,29 \\
& Junior & 112 & 82,35 \\
Asal daerah: & Medan & 10 & 7 \\
& Jakarta & 21 & 15 \\
& Bandung & 9 & 7 \\
& Semarang & 40 & 29 \\
& Yogyakarta & 18 & 13 \\
& Solo & 8 & 6 \\
& Surabaya & 12 & 9 \\
& Denpasar & 3 & 2 \\
& Mataram & 2 & 1 \\
& Makassar & 8 & 6 \\
& Manado & 5 & 4 \\
\hline
\end{tabular}

Sumber: data penelitian

\section{Pengujian Instrumen, Normalitas dan Model}

Pengujian validitas dalam penelitian ini dilakukan dengan menggunakan analisis faktor. Instrumen dikatakan valid jika memiliki KMO-MSA lebih dari 0,5 dan memiliki nilai loading factor lebih dari 0,4. Hasil uji validitas Tabel 2 menunjukkan bahwa semua indikator yang diolah dalam penelitian ini adalah valid.

Reliabilitas menunjukkan konsistensi jawaban responden apabila dilakukan pengukuran pada waktu yang berbeda. Pengujian reliabilitas dalam penelitian ini menggunakan indikator Cronbach Alpha. Hasil pengujian reliabilitas dalam Tabel 2 menunjukkan bahwa semua indikator dalam penelitian ini reliabel.

Langkah berikutnya yang dilakukan dalam penelitian ini adalah uji normalitas data untuk memastikan bahwa data yang digunakan dalam peneltian memiliki sebaran normal. Hasil olahan uji normalitas dalam Tabel 2 menunjukkan bahwa data dalam penelitian ini terdistribusi normal.

Uji model dalam penelitian ini meliputi uji koefisien determinasi dan uji pengaruh simultan ( $F$ test) yang ditunjukkan dalam Tabel 2. Uji koefisien 
determinasi digunakan untuk menguji goodness of fit dari model regresi. Hasil menunjukkan bahwa variabilitas kinerja auditor dapat dijelaskan oleh variabilitas variabel locus of control dan komitmen organisasi sebesar 17,2 persen. Setelah dilakukan uji koefisien determinasi kemudian dilakukan uji pengaruh simultan (uji F). Uji pengaruh simultan menunjukkan bahwa model fit dengan data serta variabel locus of control dan komitmen organisasi secara bersama-sama memengaruhi variabel kinerja auditor.

Tabel 2

Hasil Uji Normalitas

\begin{tabular}{lcc}
\hline Pengujian & \multicolumn{2}{c}{ Nilai Statistik } \\
\hline Uji Validitas & KMO & Loading Factor \\
Locus of control (loc) & 0,858 & 0,510 - 0,846 \\
Komitmen Organisasi (KO) & 0,920 & $0,747-0,901$ \\
Kinerja Auditor (Kin) & 0,867 & $0,517-0,871$ \\
Uji Reliabilitas (Cronbach Alpha) & \\
Locus of control (loc) & 0,901 \\
Komitmen Organisasi (KO) & 0,943 \\
Kinerja Auditor (Kin) & 0,885 \\
Uji Normalitas & \\
Kolmogorov-Smirnov Z & 1,209 \\
Signifikansi 2 sisi & 0,108 \\
Uji Model & \\
Adjusted $R$ Square & 0,172 \\
F & 15,057 \\
Signifikansi $F$ & 0,000 \\
\hline Sumber: output pengolahan data statistik dengan SPSS
\end{tabular}

\section{Pengujian Hipotesis}

Pengujian hipotesis pada penelitian ini dilakukan dengan menggunakan alat uji regresi berganda, dengan bantuan SPSS. Adapun hasil pengujian hipotesis penelitian ini tersaji dalam Tabel 3 sebagai berikut.

Tabel 3

Hasil Uji Hipotesis

\begin{tabular}{lccc}
\hline \multicolumn{1}{c}{ Variabel } & Nilai t & Nilai Signifikansi & Kesimpulan \\
\hline Locus of control & $-2,128$ & 0,035 & Hipotesis 1 didukung \\
Komitmen organisasi & 5,376 & 0,000 & Hipotesis 2 didukung \\
\hline
\end{tabular}

Sumber: output pengolahan data statistik dengan SPSS

Hipotesis pertama (H1) yang menyatakan bahwa locus of control mempunyai pengaruh negatif terhadap kinerja auditor secara statistik dapat diterima. Hasil pengujian hipotesis pertama (H1) menunjukkan bahwa taraf signifikansi bernilai lebih kecil dari 0,05. Diterimanya hipotesis ini menunjukkan bahwa auditor yang memiliki locus of control eksternal berpengaruh negatif terhadap kinerja auditor. Hasil ini menunjukkan bahwa ketika auditor tidak memiliki keyakinan bahwa hasil 
yang diperoleh dapat dikendalikan oleh dirinya sendiri, maka kinerjanya menjadi tidak maksimal. Ketika seorang auditor merasa bahwa hasil yang dilakukan lebih banyak ditentukan oleh lingkungan diluar dirinya, maka auditor kurang memiliki motivasi yang kuat untuk mencapai kinerja yang diharapkan oleh organisasi tempatnya bekerja. Temuan penelitian ini mendukung teori atribusi karena penelitian ini berhasil membuktikan bahwa sumber perilaku auditor bisa berasal dari internal auditor itu sendiri (dispositional attribution).

Hasil penelitian menunjukkan bahwa komitmen organisasi berpengaruh positif terhadap kinerja auditor, yang mendukung hipotesis dua (H2). Seorang auditor yang memiliki komitmen organisasi tinggi merasa yakin dan pasti terhadap tujuan organisasi, sehingga mereka akan berusaha mempertahankan keanggotaan dalam organisasi dan bersedia bekerja keras demi organisasi. Hasil penelitian ini mendukung teori penetapan tujuan yang membuktikan bahwa tujuan yang dimiliki oleh auditor terbukti memengaruhi perilakunya sehingga kinerjanya maksimal.

\section{SIMPULAN}

Penelitian ini dapat menyimpulkan bahwa variabel independen yang terdiri dari locus of control dan komitmen organisasi berpengaruh signifikan terhadap variabel dependen (kinerja auditor). Berdasarkan analisis yang telah dilakukan dapat ditarik kesimpulan bahwa locus of control berpengaruh negatif terhadap kinerja auditor, yang artinya semakin eksternal locus of control, seorang auditor akan cenderung memiliki kinerja tidak maksimal. Adapun komitmen organisasi berpengaruh positif terhadap kinerja auditor yang artinya semakin tinggi komitmen organisasi auditor maka kinerjanya akan semakin tinggi pula.

Penelitian ini menggunakan self-rating scale pada pengukuran kinerja sehingga memberi kemungkinan bagi para responden mengukur kinerja mereka lebih tinggi dari kinerja aktualnya. Berdasarkan pada keterbatasan yang telah disampaikan maka dapat disarankan bagi para peneliti di masa yang akan datang untuk menambahkan variabel lain misalnya budaya organisasi, gaya kepemimpinan, kompleksitas tugas atau pemahaman akan tata kelola yang baik.

Temuan penelitian ini memberikan dukungan empiris terhadap teori atribusi yang menyatakan bahwa sumber perilaku individu bisa berasal dari faktor internal dan eksternal. Individu dengan locus of control eksternal lebih memiliki keterbatasan dalam mengolah informasi sehingga kinerjanya kurang maksimal. Perilaku ini membuktikan bahwa karakteristik individu dapat memengaruhi kinerja auditor.

Hasil penelitian menunjukkan adanya pengaruh locus of control terhadap kinerja, yang menyiratkan betapa pentingnya kantor akuntan publik mengetahui locus of control individu auditor ketika organisasi hendak melakukan penerimaan terhadap auditor baru. Penelitian ini juga membuktikan pengaruh komitmen 
organisasi terhadap kinerja auditor. Temuan ini memiliki implikasi terhadap pentingnya penanaman nilai-nilai organisasi pada auditor. Penanaman nilai-nilai organisasi pada auditor dapat meyakinkan auditor akan tujuan organisasi. Meningkatnya keyakinan auditor terhadap tujuan dan nilai-nilai organisasi pada akhirnya akan meningkatkan kinerja auditor.

\section{DAFTAR PUSTAKA}

Arens, A.A., dan J.K. Loebbecke. 2013. Auditing: An Intregrated Approached. Englewood Cliffs, New Jersey: Prentice-Hall.

Blumberg, M., dan C. D. Pringle. 1982. The missing opportunity in organizational research: some implications for a theory of work performance. Academy of Management Review. Vol 7(4): 560-569.

Bonner, S. E., dan G. B. Sprinkle. 2002. The effect of monetary incentive on effort and task performance: Theories, evidence and framework of research. Accounting, Organization and Society. Vol.27 No.5: 303-345.

Donnelly, D. P., J. J. Quirin, dan D. O’Bryan. 2003. Auditor acceptance of dysfunctional audit behavior: An explanatory model using auditor's personal characteristics. Behavioral Research in Accounting. Vol.15: 87-110.

Ghozali, I. 2005. Aplikasi Analisis Multivariate dengan Program SPSS. Semarang: Badan Penerbit Universitas Diponegoro.

Irawati, Y., T. A. Petronila, dan Mukhlasin. 2005. Hubungan karakteristik personal auditor terhadap tingkat penerimaan penyimpangan perilaku dalam audit. Prosiding Simposium Nasional Akuntansi VIII Solo.

Kelley, T., dan D. Seiler. 1982. The impact of time budget pressure, personality, and leadership variables on dysfunctional auditor behavior. Auditing: A Journal of Practice \& Theory. Vol.11: 19-34.

Kelley, T., dan L. Margheim. 1990. The impact of time budget pressure personality, and leadership variables on dysfunctional auditor behavior. Auditing: A Journal of Practices \& Theory. Vol.9: 21-42.

1990. The relationship between senior auditor budget partisipation, job structuring, job consideration, and staff auditor time budget pressure. The Journal of Applied Business Research. Vol.18.

Koonce, L., dan M. Mercer. 2005. Using psychology theories in archival financial accounting research. Available at papers.ssrn.com.

Lightner, S. M., S. J. Adams, dan K. M. Lightner. 1982. The influence of situational, ethical, and expectancy theory variables on accountants' underreporting behavior. Auditing: A Journal of Practice \& Theory. Vol.2: 1-12. 
J. J. Leisering, dan A. J. Winters. 1983. Underreporting chargeable time: Its effects on client billing, future budget preparation and staff evaluation and scheduling. Journal of Accountancy. January: 52-57.

Locke, E. A., dan G. P. Latham. 1990. A Theory of Goal Setting \& Task Performance. New Jersey: Prentice Hall, Englewood Cliffs.

Luthans, F. 1998. Organizational Behaviour: Personality and Attitude. Eight Edition. New York: McGraw Hill.

Luthans, F., D. Baack, dan S. Carroll. 1987. Organizational comitment analysis of antecedents. Human Relations. Vol.40 No.4: 219-236.

Malone, C. F., dan R. W. Roberts. 1996. Factors associated with the incidence of reduced audit quality behaviors. Auditing: A Journal of Practice \& Theory. Vol.15 No.2: 49-64.

Margheim, L., dan K. Pany. 1986. Quality control, premature sign off and under reporting of time: some empirical findings. Auditing: A Journal of Practice \& Theory. Vol.7: 50-63.

Maryanti, P. 2005. Analisis penerimaan auditor atas dysfunctional audit behavior: pendekatan karakteristik personal auditor (studi empiris pada kantor akuntan publik di Jawa). Tesis. Universitas Diponegoro.

Mowday, R., L. Porter, dan R. Dubin. 1979. The measurement of organizational commitment. Journal of Vocational Behavior. Vol.14: 224-227.

Parker, R.J., dan J. M. Kohlmeyer. 2005. Organizational justice and turnover in public accountant firms: a research note. Accounting, Organizations, and Society. Vol 30: 357-369.

Robbins, S. P. 2011. Perilaku Organisasi. Jakarta: Indeks Kelompok Gramedia.

Rotter, J. B. 1966. Generalized expectancies for internal versus external control of reinforcement. Psychological Monograph. Vol.1: 601-609.

Setiawan, I. A., dan I. Ghozali. 2006. Akuntansi Keperilakuan Konsep dan Kajian Empiris Perilaku Akuntan. Semarang: Badan Penerbit Universitas Diponegoro.

Silaban, A. 2009. Perilaku disfungsional auditor dalam pelaksanaan program audit. Disertasi. Program Doktor Ilmu Ekonomi Universitas Diponegoro Semarang. Available at eprints.undip.ac.id.

Spector, P. E. 1982. Behavior in organization as a function of employee's locus of control. Psychological Bulletin. Vol.91: 482-497.

Srimindarti, C. 2010. Penerimaan perilaku audit disfungsional berdasarkan pada faktor internal individu auditor. Disertasi. Program Doktor Ilmu Ekonomi Universitas Diponegoro Semarang. Available at eprints.undip.ac.id. 
Trisnaningsih, S. 2007. Independensi auditor dan komitmen organisasi sebagai mediasi pengaruh pemahaman good governance, gaya kepemimpinan dan budaya organisasi terhadap kinerja auditor. Prosiding Simposium Nasional Akuntansi $X$.

Wijayanti, P., dan I. Kartika. 2007. Locus of control sebagai anteseden hubungan kinerja pegawai dan penerimaan perilaku disfungsional audit (studi pada auditor pemerintah yang bekerja pada BPKP di Jawa Tengah dan DIY). Prosiding Simposium Nasional Akuntansi X.

Wijaya, R. 2014. Pengaruh independensi, komitmen organisasional, gaya kepemimpinan, budaya organisasi, motivasi dan locus of control terhadap kinerja auditor (studi empiris pada KAP di Semarang). Skripsi. Universitas Katolik Soegijapranata.

Yunanto, R. 2014. Pengaruh independensi, komitmen organisasional, gaya kepemimpinan, budaya organisasi, self esteem dan self efficacy terhadap kinerja auditor (studi empiris pada KAP di Semarang). Skripsi. Universitas Katolik Soegijapranata Semarang. 


\section{LAMPIRAN}

Tabel 4

Indikator Empiris Variabel Penelitian

\begin{tabular}{|c|c|}
\hline Kode & Uraian \\
\hline \multicolumn{2}{|c|}{ Locus of control } \\
\hline LOC1 & Saya berpendapat bahwa pekerjaan merupakan sesuatu yang harus saya kerjakan. \\
\hline LOC2 & $\begin{array}{l}\text { Pada kebanyakan pekerjaan, saya dapat dengan mudah menyelesaikan apapun yang saya } \\
\text { tetapkan untuk diselesaikan. }\end{array}$ \\
\hline LOC3 & $\begin{array}{l}\text { Jika saya tahu apa yang saya inginkan dari pekerjaan, saya bisa menyelesaikan pekerjaan } \\
\text { dengan baik. }\end{array}$ \\
\hline LOC4 & $\begin{array}{l}\text { Jika karyawan tidak setuju dengan keputusan atasan, mereka seharusnya melakukan } \\
\text { sesuatu untuk hal tersebut. }\end{array}$ \\
\hline LOC5 & Mendapatkan pekerjaan yang saya inginkan merupakan masalah keberuntungan semata. \\
\hline LOC6 & Menghasilkan uang adalah semata-mata masalah keberuntungan. \\
\hline LOC7 & Kebanyakan orang mampu mengerjakan tugasnya dengan baik jika mereka berusaha. \\
\hline LOC8 & $\begin{array}{l}\text { Agar supaya mendapatkan pekerjaan yang benar-benar bagus, saya harus mempunyai } \\
\text { anggota keluarga atau teman yang mempunyai posisi tinggi. }\end{array}$ \\
\hline LOC9 & Promosi biasanya merupakan masalah keberuntungan. \\
\hline LOC10 & $\begin{array}{l}\text { Ketika memperoleh pekerjaan yang sangat bagus, siapa yang saya kenal lebih penting, } \\
\text { daripada keahlian dan kemampuan yang saya miliki. }\end{array}$ \\
\hline LOC11 & Promosi akan diberikan pada pegawai yang berkinerja baik. \\
\hline LOC12 & Untuk menghasilkan banyak uang saya harus mengetahui orang-orang yang tepat. \\
\hline LOC13 & Diperlukan banyak keberuntungan untuk menjadi karyawan yang berprestasi. \\
\hline LOC14 & Pegawai yang berkinerja baik seharusnya mendapat reward. \\
\hline LOC15 & $\begin{array}{l}\text { Kebanyakan pegawai lebih berpengaruh terhadap atasannya daripada yang pegawai } \\
\text { tersebut pikirkan. }\end{array}$ \\
\hline LOC16 & $\begin{array}{l}\text { Perbedaan utama antara orang yang menghasilkan banyak uang dan orang yang sedikit } \\
\text { menghasilkan uang adalah keberuntungan. }\end{array}$ \\
\hline KO1 & Saya bersedia berusaha keras melebihi yang diharapkan supaya organisasi ini sukses. \\
\hline $\mathrm{KO} 2$ & Saya berbicara pada teman bahwa organisasi saya bekerja adalah organisasi yang bagus. \\
\hline KO3 & Saya akan menerima semua bentuk penugasan supaya tetap bekerja pada organisasi ini. \\
\hline $\mathrm{KO} 4$ & Saya menemukan kesamaan antara nilai-nilai saya dan nilai-nilai organisasi. \\
\hline KO5 & Saya bangga menceritakan pada orang lain bahwa saya adalah bagian dari organisasi ini. \\
\hline KO6 & Organisasi ini sungguh-sungguh memberikan inspirasi untuk bekerja dengan baik. \\
\hline KO7 & $\begin{array}{l}\text { Saya sangat bahagia memilih bergabung dengan organisasi ini sebagai tempat bekerja } \\
\text { daripada organisasi lainnya, ketika saya pertama kali memutuskan untuk bergabung } \\
\text { dengan organisasi ini. }\end{array}$ \\
\hline KO8 & Bagi saya organisasi ini adalah tempat yang terbaik untuk bekerja. \\
\hline KO9 & Saya sungguh-sungguh peduli terhadap nasib organisasi ini. \\
\hline KIN1 & $\begin{array}{l}\text { Kinerja saya tergantung pada perencanaan (missal penentuan tujuan dan kebijakan, } \\
\text { penganggaran dan penyiapan agenda). }\end{array}$ \\
\hline KIN2 & Kinerja saya tergantung pada pengumpulan dan penyiapan informasi, laporan keuangan. \\
\hline KIN3 & $\begin{array}{l}\text { Kinerja saya tergantung pada koordinasi (pertukaran informasi, mengatur pertemuan, } \\
\text { saling menasehati). }\end{array}$ \\
\hline KIN4 & $\begin{array}{l}\text { Kinerja saya tergantung pada supervisi (pengarahkan,kepemimpinan, penasehatan dan } \\
\text { pemberian pelatihan terhadap bawahan). }\end{array}$ \\
\hline KIN5 & Kinerja saya tergantung pada cara pemilihan staff (perekrutan, wawancara dan promosi). \\
\hline KIN6 & Kinerja saya tergantung pada keterwakilan (menindaklanjuti tujuan umum organisasi). \\
\hline KIN7 & $\begin{array}{l}\text { Kinerja saya tergantung pada perencanaan, investigasi, koordinasi, supervisi, pemilihan } \\
\text { staff dan keterwakilan secara keseluruhan }\end{array}$ \\
\hline
\end{tabular}


